\title{
Editorial: Archives of humans, environments and their interactions - papers in honour of Professor C. Neil Roberts and Professor Henry F. Lamb
}

\author{
Melanie J. Leng ${ }^{1}$, Warren Eastwood ${ }^{2}$ and Matthew D. Jones ${ }^{3}$
}

${ }^{1}$ NERC Isotope Geosciences Facilities, British Geological Survey, Keyworth, Nottingham, NG12 5GG, UK and Centre for Environmental Geochemistry, School of Biosciences, University of Nottingham, Leicestershire, LE12 5RD, UK

${ }^{2}$ School of Geography, Earth and Environmental Sciences, University of Birmingham, Birmingham, B15 2TT, UK

${ }^{3}$ School of Geography, University of Nottingham, Nottingham, NG7 2RD, UK

This special issue of QSR comprises a series of papers written to celebrate the careers of Neil Roberts (Professor of Physical Geography) and Henry Lamb (Professor of Quaternary Science), as they retire from full-time posts. Both Henry's and Neil's research careers have been exceptional, marked by novel, cutting-edge research of the very highest quality within cognate disciplines and which address the big questions in Quaternary Science. Both have promoted the importance of environmental change; Neil primarily in the 'sea in the middle of the earth' (i.e., the lands bordering the Mediterranean) and Henry in tropical east Africa and Morocco. Both have made immense contributions to our understanding of global change in the Quaternary and have been instrumental in raising the discipline to new levels of scientific rigour. They both have CVs listing over 100 publications and still counting. This volume is an opportunity to celebrate their work and say thanks.

\section{Neil's research career...}

Neil started his academic career with a BA Hons degree in Geography followed by a Diploma in Prehistoric Archaeology from Oxford University. Neil completed his PhD at University College London in 1980, supervised by Professor Claudio Vita-Finzi, on the Late Quaternary geomorphology and palaeoecology of the Konya basin (Turkey) and undertook further research as a Post-doctoral Research Associate at the School of Geography, University of Oxford, working on the famous lake level data base with Professor Alayne Street-Perrott. Neil was appointed to a Lectureship in Physical Geography at Loughborough University in 1981 and by 1995 had become a Reader in Physical Geography. Neil took up the post of Professor of Physical Geography at Plymouth University in 1998. 
Neil's principal research contribution has been in understanding the nature and causes of climatic and other environmental changes which have occurred in the most recent phase of Earth history: the Holocene (after which his well-known textbook, first published in 1989 and now on the $3^{\text {rd }}$ edition, is named). This research has focussed, in particular, on environmental changes which have occurred in dryland regions of the world, via the natural "archive" preserved in the sediments of lake basins. Perhaps most notable is his work on the analysis of lake sediment archives, or palaeolimnology, involving a wide range of laboratory and field techniques, of which diatom and stable isotope analyses has been especially significant. Diatoms, isotopes and other palaeolimnological data reflect past changes in water level and chemistry which in turn are a product of hydrological and climatic factors over the lake catchment. A prime objective of Neil's work has been to establish regional changes in climate, particularly water balance, over decadal to millennial timescales. Following his post-doctoral work an underlying task has been to map the extent of the palaeo-monsoon, and to assess the indirect effects of changes in the intensity and extent of the monsoon on adjacent climatic zones. For example, his work established the extent of early Holocene "monsoonal" rainfall in Southwest Asia and North Africa and contributed to larger global palaeoclimatic syntheses, such as that undertaken by the COHMAP group (Cooperative Holocene Mapping Project), and the PEPIII transect of the Past Global Changes (PAGES) programme.

Neil has studied sub-Milankovitch climate changes from the record of lake-level fluctuations latitudinally from Africa through Eurasia. Major field research programmes investigating lake-level and salinity fluctuations have been carried out, notably in Turkey and Morocco. These studies include comparison of multi-proxy indicators of Holocene climate change, notably diatom-based lake-level records, ostracod, mollusc, geochemical, stable isotope, pollen and sedimentological analyses, along with dealing with local challenges associated with dating techniques.

In the early 1990's Neil initiated a research programme on environmental history in the eastern Mediterranean region which illustrated a second major cause of change which may be revealed by analysis of sedimentary records, namely human activities. The objective of this work has been to investigate the palaeoenvironmental record of landscape transformation associated with agriculture and pastoralism in regions whose history of settlement is long and well-attested. Many of these cultural changes, such as plant and 
animal domestication, were influenced by climatic changes, particularly during the last glacial to interglacial transition. This work has also included close collaboration with historians and archaeologists, including at the Turkish site of Çatalhöyük.

In more recent times, Neil has been engaged in transforming pollen as "big data" into large-scale land cover change during the Holocene, initially on a pan-European scale, and subsequently for the Mediterranean.

Neil retired from Plymouth in 2018 and is now a Visiting Researcher at the University of Oxford, Emeritus Professor at the University of Plymouth and an Honorary Doctor of Ankara University, alongside his new duties as a grandpa.

\section{Henry's research career...}

Henry started his academic career with a BA Hons degree in Natural Sciences (Botany) from Trinity College, Dublin followed by an MSc in Ecology from the University of Minnesota supervised by the late Herb Wright Jr. It was at Minnesota where Henry honed his skills in Quaternary Science working for his Masters on the Late Quaternary vegetational history of southeastern Labrador, Canada. Henry further researched Late Quaternary dynamics of the forest ecotone in Labrador as his PhD at Sidney Sussex College, University of Cambridge under the supervision of Professor John Birks and was awarded a Research Fellowship to Sidney Sussex College in 1981 to continue his palynological work in Labrador. After his PhD and Post Doctoral Fellowship, Henry headed west to Wales where he was appointed to a Lectureship in Physical Geography at Aberystwyth University in 1983 and took up his current post of Professor of Quaternary Science in 2013.

Henry's research expertise is in environment-human interactions via analysis of lake sediment cores, pollen and X-ray fluorescence geochemistry of lacustrine sediments and his early research was centred on projects working in Morocco and Turkey (some of these with Neil). Since the early-mid 1990s, Henry's research has focussed on the environmental history of eastern Africa during the last 500,000 years focussing on how climatic changes may have influenced the origin and dispersal of early modern humans. This is now part of the Hominin Sites and Paleolakes Drilling Project, an international scientific collaboration on palaeoclimate and human evolution and based on sediment cores retrieved close to some of the world's most important fossil hominin sites. Henry is one of the leading 
scientists of the 'Chew Bahir Project' which aims to reconstruct the palaeoenvironmental record of the Chew Basin in southern Ethiopia; some of this research is reported in this issue. Collaborative research features highly in Henry's career and he works with partners from the Universities of Cologne, Potsdam, and Addis Ababa on the DFG-supported 'Our Way to Europe' project investigating climate change and archaeology of Ethiopia. He also collaborates on the multi-disciplinary 'Mountain Exile Hypothesis' project that aims to document and understand the Pleistocene and Holocene history of human occupation of the afro-montane and afro-alpine ecosystems in the Bale Mountains, Ethiopia.

Henry is currently working part time at Aberystwyth University, in part focusing on his research interests closer to home, the cross-disciplinary CHERISH Project. This is a European-funded Ireland-Wales project to raise awareness and understanding of the past, present and near-future impacts of climate change and extreme weather events on the cultural heritage of the Irish and Welsh coasts. Henry and his wife Emma are also undertaking a restoration of their ancestral home in Ireland. Following in the family tradition (his father was JGD Lamb one of Ireland's foremost horticultural scientists and gardeners), Henry is nurturing an orchard of Irish apple varieties in the grounds.

\section{Summary of this volume}

Henry and Neil have inspired and mentored a second and third generation of Quaternary scientists, including a good number who are now professors and scientific leaders in their own right. The papers in this special issue, co-authored by former PhD students, colleagues, collaborators and friends are testament to their contributions to the advancement in Quaternary science.

There are sets of papers focussed in the geographical areas where Neil and Henry have done much of their work.

There are a series of papers from recent work in Ethiopia. Asrat et al. discuss climate change around the last interglacial based on evidence from annually resolved speleothem records and Roberts, $\mathbf{H}$. et al. consider the use of luminescence dating for long lacustrine sediment records, presenting data from Lake Tana. Loakes et al. present a diatom and pigment record from Lake Hayk and Viehberg et al. discuss results from Chew Bahir in relation to Homo sapiens expansion through MIS4 and MIS3. From elsewhere in Africa Mills et al. discuss using novel geochemical techniques on a core from Uganda to look at 
the complexity of aquatic response to catchment and with-in lake changes and Bristow et al. present new data from Lake Megachad at the end of the African Humid Period.

From the Mediterranean Zanchetta et al. and Lacey and Jones discuss new results and analysis from the carbon and oxygen isotope records respectively from Lake Ohrid.

Sadori presents a Lateglacial and Holocene vegetation record from Lago di Mezzano, discussing the impacts of people and climate on the vegetation of that region. From the edge of the Mediterranean zone Parton et al. present new data from lake and wetland deposits in the Nefud Desert, Northern Arabia.

There is also work from further afield, but developing themes that Henry and Neil have focussed on at various stages of their careers. Cadd et al. discuss a new multi-proxy record from Welsby Lagoon in Queensland, Australia and Tibby et al. discuss some of the issues in interpreting proxy data from Australian core records during the period of European settlement. Anderson et al. take a landscape perspective to discuss organic carbon cycling in Greenland lakes. Jones and Dee take a global view in discussing the issues around proxy data - climate model comparisons with a focus on lake carbonate isotope records.

It was not difficult to find contributions to this set of papers, and there were many kind words and happy memories shared with us about Henry and Neil as it came together, including from colleagues who could not contribute papers to this volume. We wish Neil and Henry well in their new career phases and look forward to continued collaboration. 